\title{
Effect of Organic Manuring and Integrated Nutrient Management on Microbiological Properties in Sandy Soils under Wheat-Guar Cropping System
}

\author{
Nisha Verma* and Sneh Goyal
}

Department of Microbiology, CCS Haryana Agricultural University, Hisar, Haryana, India

*Corresponding author

\section{A B S T R A C T}

\begin{tabular}{|l|}
\hline Ke y w o r d s \\
Farm Yard Manure \\
(FYM), \\
$\begin{array}{l}\text { Vermicompost } \\
\text { (VC), Microbial } \\
\text { biomass, Soil } \\
\text { microbiological } \\
\text { properties }\end{array}$ \\
\hline Article Info \\
\hline $\begin{array}{l}\text { Accepted: } \\
\text { 15 January } 2018 \\
\text { Available Online: } \\
\text { 10 February } 2018\end{array}$ \\
\hline
\end{tabular}

The long-term application of excessive chemical fertilizers has resulted in the degeneration of soil quality parameters such as soil microbial biomass and nutrient content, which in turn affects crop health, productivity, and soil sustainable productivity. Organic manuring and Integrated nutrient management system (INMS) gained importance in maintaining the soil health and fertility. The continuous application of vermicompost (VC) for ten years @ $15 \mathrm{t}$ /ha under wheat-guar cropping system at Bawal in sandy soils had beneficial effects on soil microbiological properties compared to conventional system using only chemical fertilizers. Organic $\mathrm{C}$ and total $\mathrm{N}$ increased from 0.163 to 0.270 and from 0.012 to $0.076 \%$, respectively. The total $\mathrm{P}$, available $\mathrm{P}$ and available $\mathrm{N}$ were $152,8.0$ and $29 \mathrm{mg} / \mathrm{kg}$ soil, respectively. The amount of total $\mathrm{K}$ varied from 1530 to 2019 and $\mathrm{Zn}$ from 126 to 175 $\mathrm{mg} / \mathrm{kg}$ soil. The $\mathrm{C}$ mineralization rate and potentially mineralizable nitrogen were 6.8 and $41.5 \mathrm{mg} / \mathrm{kg}$ soil, respectively and were highest in treatment receiving VC @ $15 \mathrm{t} / \mathrm{ha}$. Microbial biomass $\mathrm{C}$ (MBC), microbial biomass $\mathrm{N}(\mathrm{MBN})$ and microbial biomass $\mathrm{P}$ (MBP) were 320,40 and $12 \mathrm{mg} / \mathrm{kg}$ soil. The biomass $\mathrm{C} / \mathrm{N}$ ratio ranged from 6.4 to 8.0 and $\mathrm{C} / \mathrm{P}$ ratio from 20.0 to 26.6 , and was highest treatment with VC @ 15t /ha.

\section{Introduction}

Soil is a natural habitat that support plant growth. The long term use of chemical fertilizers damages the soil physical properties and causes environmental pollution (Sangshetty and Babalad, 2011). In many parts of Haryana, due to continous use of chemical fertilizers, the level of soil organic matter has gone down.To build up or to maintain the level of soil organic matter in agricultural soil, use of organic amendments or integrated use of chemical fertilizers along with organic amendments is being advocated and opted by many farmers in Haryana.The complementary use of chemical fertilizers, biofertilizers, organic manures and crop residues can ensure long-term nutrient supply and soil productivity (Anik et al., 2017).Different management systems may result in changes in different nutrient release pattern and soil microbial community which may affect plant growth (Araujo et al., 2008). The soil microbial biomass is a much more 
labile component of soil organic matter than most of the other fractions (Sangshetty and Babalad, 2011). Low inputs of organic materials, excessive use of mineral fertilizers and more frequent tillage have contributed to a general reduction in soil organic matter (SOM) content, with a consequent decline in the quality of agricultural soils (Chang et al., 2014). This negative effect of agricultural practices could be reversed by the correct utilization of manures and/or crop residues within cropping systems, either alone or in combination with mineral fertilizers (Mandal et al., 2007). But any increase in SOM content due to organic matter addition may be slow. However, whilst the amount of $\mathrm{C}$ stored in soil is a good indicator of soil quality, it does not necessarily reflect the complexity of the organic compounds present and the influence that these may have on the microbiological processes controlling nutrient availability.

To overcome these limitations, different authors have proposed several soil indicators to study the effects of organic manure applications on soil $\mathrm{C}$ accumulation and $\mathrm{C}$ and $\mathrm{N}$ turnover (Gil-Sotres et al., 2005). Some are based on soil physical and chemical properties but the majority focuses on biochemical properties that reflect the size and activity of microbial processes. This is because biologically mediated processes in soils play a key role in the mineralization of organic $\mathrm{C}$ and in nutrient cycling. Moreover, changes in the size and activity of the soil microbial biomass occur more rapidly in response to changes in environmental conditions, land use and management than most physical and chemical parameters (Frazao et al., 2010).

The biochemical properties are more sensitive to environmental stress which play a major role in degradation, and provide rapid and accurate information on soil quality (García et al., 2000). While biochemical properties of the soil can be studied at various levels, the most relevant are those involved in transformation of organic matter (Leirós et al., 2000). The biochemical parameters include variables directly related to microbial activity (microbial biomass $\mathrm{C}$, soil respiration etc.) and the activities of extracellular hydrolytic enzymes involved in the $\mathrm{C}, \mathrm{N}, \mathrm{S}$ and $\mathrm{P}$ cycles in soil. These soil biochemical and microbiological parameters are considered as potential indicators of management impacts on soil quality (GilSotres et al., 2005; Mahmood et al., 2017) especially under different agricultural management practices because soil microbial biomass and enzyme activities respond much more quickly to the changes in soil management practices as compared to total soil organic matter (Garcia-Ruiz et al., 2008). The response of these soil biochemical and microbial variables to organic and conventional amendments is often studied in the long-term (Monaco et al., 2008).

Therefore, understanding of soil biological processes that liberate plant nutrients is needed for soils receiving organic amendments or integrated use of chemicals fertilizers along with organic manures under tropical regions.

\section{Materials and Methods}

\section{Experimental design and treatments}

The field experiment on wheat-guar cropping system consisted of fifteen treatments along with a control in a randomized block design with four replications.

\section{Soil sampling and its preparations}

Soil samples were collected from ten different locations with different treatments fertilized with organic manures and combination of 
organic and inorganic nutrient sources from 0-15 cm layer in crop rotation systems from bawal.

Soil samples amended with organic and inorganic manures from last three to thirteen years were drawn from research farm. The soil samples were sieved through $2 \mathrm{~mm}$ sieve and stored at $4^{\circ} \mathrm{C}$. For determination of microbial biomass and microbial activities, the soil was moistened to 60 per cent water holding capacity (WHC) and incubated at $30^{\circ}$ $\mathrm{C}$ for 10 days to permit uniform rewetting and to allow microbial activity to equalibriate after the initial disturbances. Sub-samples of each soil were air-dried and ground for chemical analysis. Soil samples were analysed for chemical and biological properties.

\section{Analytical methods}

\section{Soil chemical properties}

Five gram soil was mixed with $12.5 \mathrm{ml}$ of distilled water. It was shaken for $30 \mathrm{~min}$ and $\mathrm{pH}$ of soil suspension was measured at room temperature with Systronics $331 \mathrm{pH}$ meter and Electrical Conductivity (EC) was measured with Naina electrical conductivity meter, as per the procedure given by Jackson (1973). The organic C in soil samples was determined by method of Kalembassa and Jenkinson (1973). The alkaline potassium permanganate oxidizable soil $\mathrm{N}(\mathrm{KMnO} 4-\mathrm{N})$ as an index of available $\mathrm{N}$ was determined as per the procedure given by Subbiah and Asija (1956). Olsen-P was extracted with $0.5 \mathrm{M}$ sodium bicarbonate $(\mathrm{pH} 8.5)$ as outlined by (Olsen et al., 1954) and the $\mathrm{P}$ content in the extract was deter-mined by a spectrophotometer. Available $\mathrm{K}$ was determined in the neutral normal ammonium acetate extract of soil with the help of flame photometer (Jackson, 1973). Available Zn was determined by method of Lindsay and
Norvell (1978) using atomic absorption spectrophotometer.

\section{Ammoniacal nitrate - nitrogen and carbon mineralization}

Ammoniacal and Nitrate - Nitrogen were estimated by steam distillation method of Keeney and Bremner (1965). Carbon Mineralization was determined by measuring $\mathrm{CO}_{2}$ evolution from soil for 4 weeks by method of Pramer and Schmidt (1964) with slight modification. Soil basal respiration (respiration rate) was estimated by placing $100 \mathrm{~g}$ of oven-dried equivalent of field-moist soil in a tube and incubating the sample in the dark in a 500-mL airtight Duran bottle along with $10 \mathrm{~mL}$ of sodium hydroxide $(\mathrm{NaOH})$ to absorb carbon dioxide $\left(\mathrm{CO}_{2}\right)$. The carbon dioxide carbon $\left(\mathrm{CO}_{2}-\mathrm{C}\right)$ was determined by titration.

\section{Microbial biomass $\mathbf{C}, \mathbf{N}$ and $\mathbf{P}$}

Soil microbial biomass $\mathrm{C}, \mathrm{N}$ and $\mathrm{P}$ were measured by standard estimation procedures. Microbial biomass carbon, biomass nitrogen and phosphorus, was estimated by method described by Vance et al. (1987), Pruden et al. (1985) and Brookes et al. (1982). Soil microbial carbon (MBC) and soil microbial nitrogen (MBN) were determined by $24 \mathrm{~h}$ chloroform fumigation followed by extraction with $0.5 \mathrm{M}$ potassium sulfate $\left(\mathrm{K}_{2} \mathrm{SO}_{4}\right)$. The amount of $\mathrm{CO}_{2}$ evolved was determined by subtracting the fumigated soil from that of unfumigated one. For microbial biomass $\mathrm{P}$ analysis, $5 \mathrm{~g}$ of field-moist soil was weighed into a crucible and fumigated in a desiccator with $50 \mathrm{ml}$ of alcohol-free chloroform for 5 days. Hundred millilitres of sodium bicarbonate extracting solution was used to shake both fumigated and unfumigated soil samples for 30 minutes. Soil samples not fumigated were equilibrated simultaneously with a series of $\mathrm{P}$ containing standard 
solutions as correction for adsorption of $\mathrm{P}$ during fumigation. The amount of chloroform released $\mathrm{P}$ was determined according to the relationship between $\mathrm{P}$ added (from standard solutions or microbial lysis) and P extracted.

\section{Results and Discussion}

\section{Soil chemical properties}

The chemical properties of soil such as $\mathrm{pH}$, organic $\mathrm{C}$, total $\mathrm{N}$, available $\mathrm{N}$, total $\mathrm{P}$, available $\mathrm{P}$, total $\mathrm{K}$, total $\mathrm{Zn}$ are influenced by various short and long term crop management practices such as crop rotations, organic manuring and chemical fertilizers.

Soil chemical properties of wheat-guar rotation system at research farm Bawal after ten years of application of organic amendments are presented in Table 1. The soil $\mathrm{pH}$ ranged from 7.05 to 7.62 . The $\mathrm{pH}$ of soil receiving vermicompost (VC) was higher as compared to other treatments. The electrical conductivity (EC) of soils ranged from 0.12 to $0.29 \mathrm{dS} / \mathrm{m}$. No significant difference in $\mathrm{pH}$ and $\mathrm{EC}$ was observed in soils receiving different organic amendments. Soil organic $\mathrm{C}$ was higher in treatments receiving organic amendments and a combination of organic manures and inorganic fertilizers as compared to soils receiving inorganic fertilizers alone. Organic $\mathrm{C}$ increased from 0.163 to $0.270 \%$. The highest amount of organic $\mathrm{C}$ was observed in soils which received VC@15t /ha and least organic C was observed in unfertilized (control) soils. Organic C was $3.1 \%$ higher in soil receiving $\mathrm{VC}$ than the soil receiving (Farm Yard Manure) FYM @15t /ha. Appireddy et al. (2008) monitored the comparative performance of five varieties of bell pepper (Capsicum annuиm L.) and observed changes in soil properties under organic and integrated nutrient management (INM) systems. They reported higher soil $\mathrm{pH}$ and organic carbon in the plots treated with organic manures alone as compared to INM.

There was a significant difference in total $\mathrm{N}$ content of soils receiving different organic amendments. The total $\mathrm{N}$ increased from 0.012 to $0.076 \%$ and was $4.1 \%$ more in treatment which received VC @ $15 \mathrm{t} / \mathrm{ha}$ than VC@10t/ha+100\% RF (Recommended Fertilizer). Gharib et al. (2008) studied the effect of compost and biofertilizers on the growth, yield and oil constituents of marjoram (Majorana hortensis L.). The soil $\mathrm{pH}$ was found to be 7.10. Organic carbon and total nitrogen were 0.29 and $0.01 \%$, respectively.

The available $\mathrm{N}$ increased from 11 to 29 $\mathrm{mg} / \mathrm{kg}$ and was highest in treatment with VC@15t /ha. Application of fertilizers and manures resulted in significant improvement in the buildup of the available $\mathrm{N}$ content of subsurface soil. So, it is clear that application of organic manures in conjunction with chemical fertilizers increased the available $\mathrm{N}$ in soil is attributed to the increase in total SOC that might have been partially due to a slow release of $\mathrm{N}$ from straw and manure as suggested by Gami et al., (2001) and Bhandari et al., (2002). Total P and available $\mathrm{P}$ were significantly higher in soils receiving VC, FYM, combination of FYM and inorganic fertilizers. The total $\mathrm{P}$ and available $\mathrm{P}$ were 152 and $8.0 \mathrm{mg} / \mathrm{kg}$ soil, respectively. Amount of total K varied from 1530 to 2019 and total $\mathrm{Zn}$ from 126 to $175 \mathrm{mg} / \mathrm{kg}$ soil. Available $\mathrm{P}$ and $\mathrm{K}$ also have been shown to increase in soils under organic management systems (Clark et al., 1998). Sangshetty and Babalad (2011) studied the effect of different sources of organic manures on soil chemical properties under organic cotton production system on the nutrient uptake, nutrient status of the soil after the harvest of cotton genotypes and reported that soil available N, $\mathrm{P}$ and $\mathrm{K}$ were significantly higher with $\mathrm{RDF}+$ FYM $(360.50,60.50$ and $495.33 \mathrm{~kg}$ NPK/ha, 
respectively). Mahmood et al. (2017) studied the effects of organic and inorganic manures on maize and their residual impact on soil physico-chemical properties

\section{Carbon mineralization rate}

The evolution of $\mathrm{CO}_{2}$ from soil is a total sum of respiration and carbon mineralization by soil biota and is a sensitive indicator of soil organic matter turnover.

Carbon mineralization rate as affected by different organic amendments in wheat-guar rotation system at Bawal has been compiled in Table 2. The amount of $\mathrm{CO}_{2}$ evolution was higher in all the treatments during first week of incubation and it decreased with further incubation with least amount of $\mathrm{CO}_{2}$ evolved in fourth week of incubation. The rate of carbon mineralized ranged from 3.3 to 6.8 $\mathrm{mg} / \mathrm{kg}$ soil/28 day. The $\mathrm{C}$ mineralization rate was lower in inorganically fertilized soils compared to soils receiving organic manures and a combination of organic manures and inorganic fertilizers. The highest $\mathrm{C}$ mineralization rate was observed in soils receiving VC@15t /ha and lowest in soils receiving recommended dose of fertilizers. Sharma et al. (2011) found that there was a significant increase in carbon mineralization, soil microbial biomass carbon and soil dehydrogenase activity with the organic amendment. The maximum increase in soil microbial activities were found when sole organic source (farm yard manure $(50 \%)+$ biofertilizer $(25 \%)+$ green manure $(25 \%)$ has been used in combination with the conservation tillage and the optimum water supply.

Figure.1 Microbial biomass $\mathrm{C}$ as affected by different organic and inorganic amendments in wheat-guar rotation system at research farm Bawal

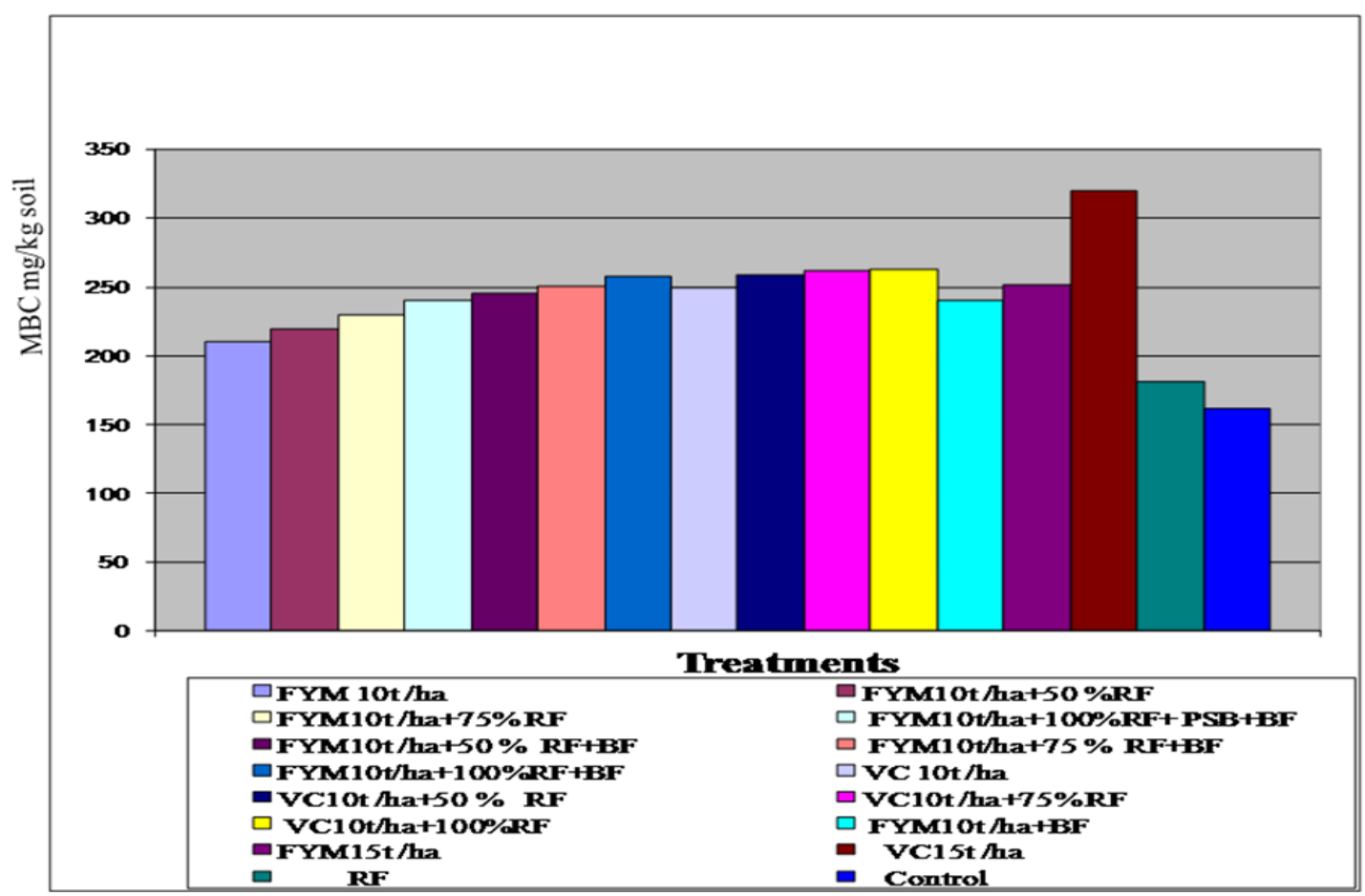


Figure.2 Microbial biomass $\mathrm{N}$ as affected by different organic and inorganic amendments in wheat-guar rotation system at research farm Bawal

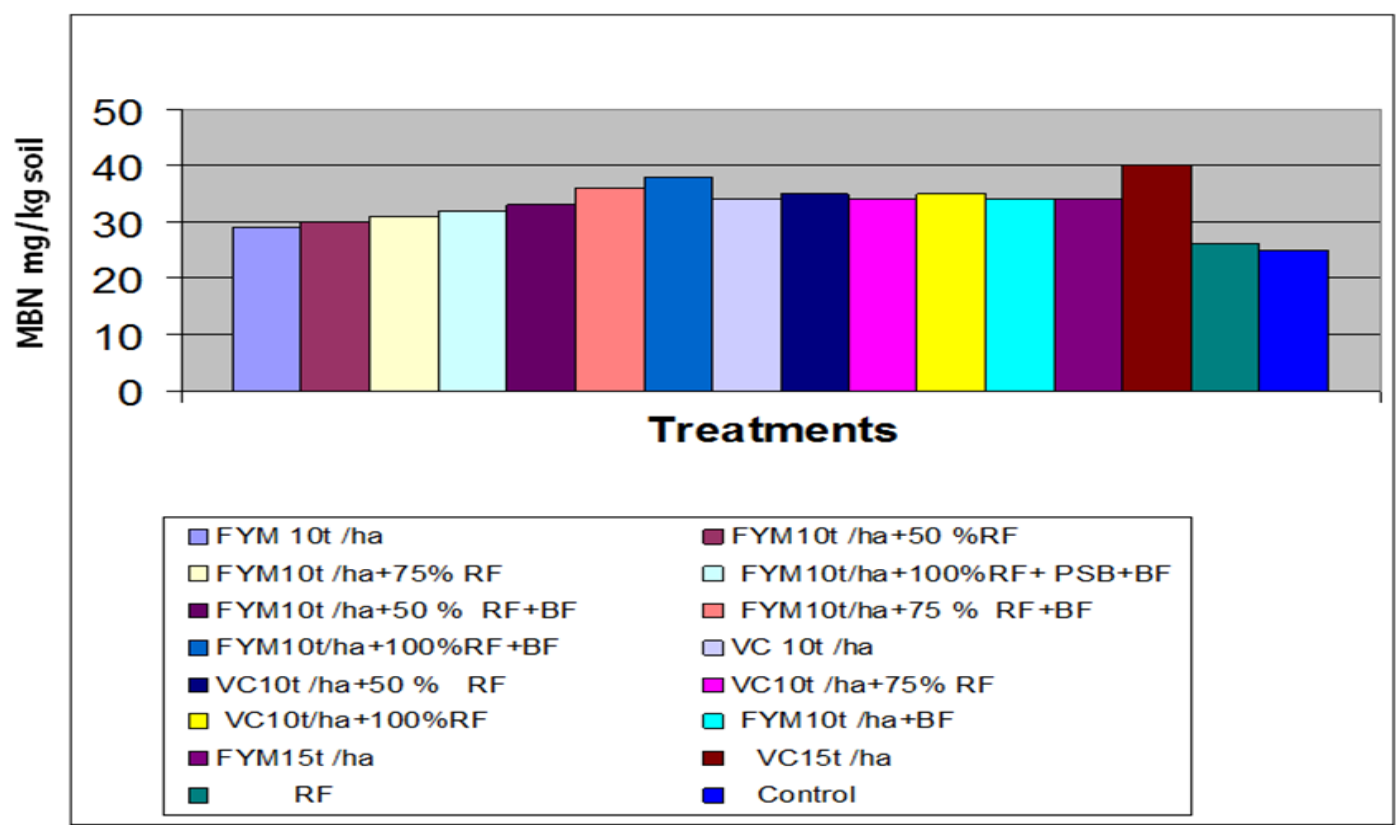

Figure.3 Microbial biomass $\mathrm{P}$ as affected by different organic and inorganic amendments in wheat-guar rotation system at research farm Bawal

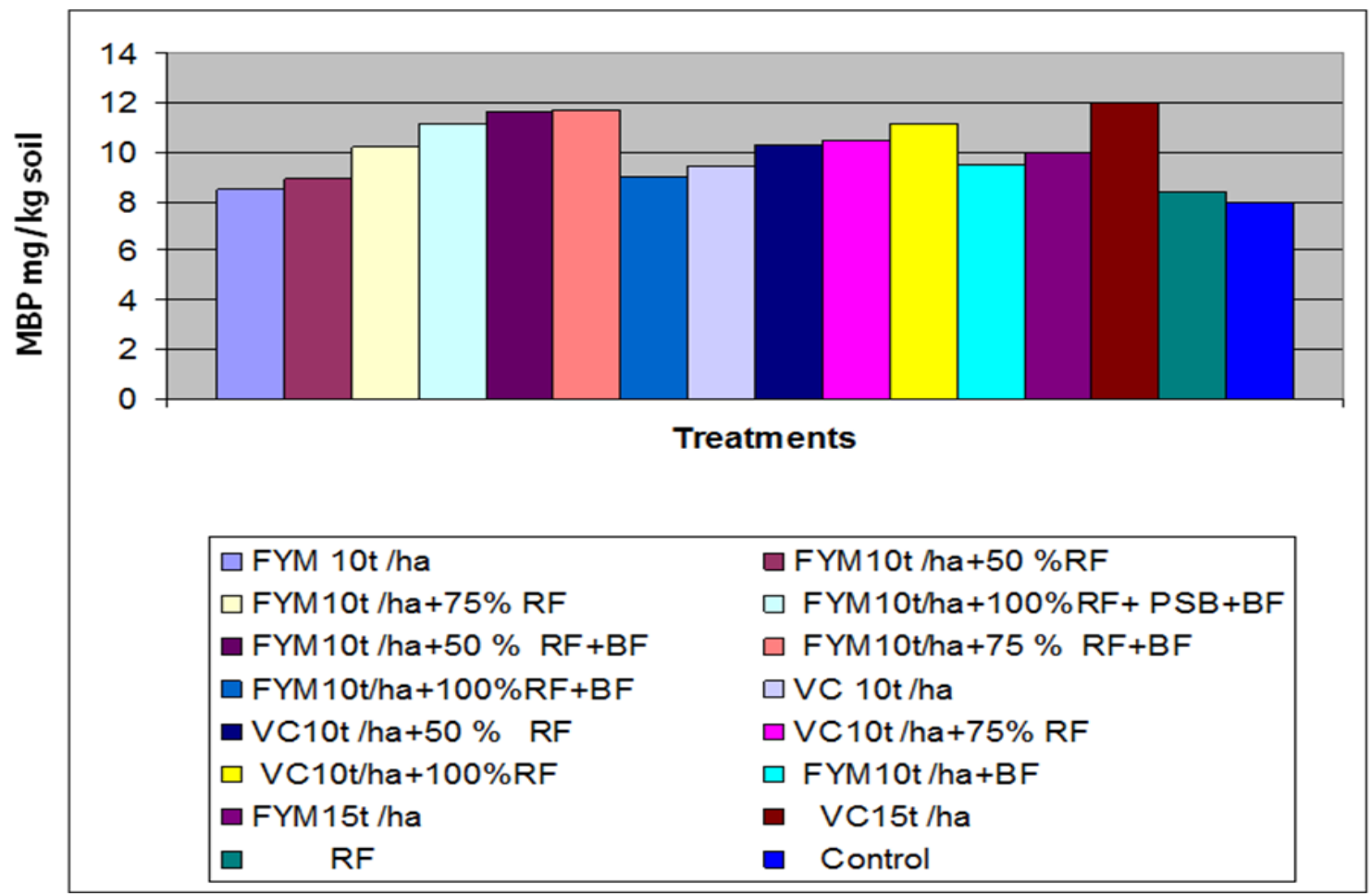


Table.1 Effect of different organic and inorganic amendments on soil chemical properties in wheat-guar rotation system at research farm Bawal

\begin{tabular}{|c|c|c|c|c|c|c|c|c|c|}
\hline Treatments & $\begin{array}{c}\text { pH } \\
(1: 2.5) \\
\text { ratio }\end{array}$ & $\begin{array}{c}\text { EC } \\
(d S / m)\end{array}$ & $\begin{array}{c}\text { Organic } \\
\text { C } \\
(\%)\end{array}$ & $\begin{array}{c}\text { Available } \\
\text { P } \\
\text { (mg/kg } \\
\text { soil) }\end{array}$ & $\begin{array}{c}\text { Total } \\
\text { P } \\
\text { (mg/kg } \\
\text { soil) }\end{array}$ & $\begin{array}{c}\text { Total } \\
\text { N } \\
(\%)\end{array}$ & $\begin{array}{c}\text { Available } \\
\text { N } \\
\text { (mg/kg } \\
\text { soil) }\end{array}$ & $\begin{array}{c}\text { Total } \\
\text { K } \\
\text { (mg/kg } \\
\text { soil) }\end{array}$ & $\begin{array}{c}\text { Total } \\
\text { Zn } \\
\text { (mg/kg } \\
\text { soil) }\end{array}$ \\
\hline FYM 10t /ha & 7.14 & 0.21 & 0.208 & 4.2 & 80.2 & 0.040 & 13 & 1900 & 129 \\
\hline FYM 10t /ha+50 \% RF & 7.19 & 0.23 & 0.225 & 4.7 & 92.8 & 0.042 & 15 & 1940 & 133 \\
\hline FYM 10t /ha+75\% RF & 7.25 & 0.22 & 0.231 & 4.8 & 99 & 0.044 & 14 & 1960 & 136 \\
\hline FYM10t/ha+100\% RF+PSB+BF & 7.31 & 0.26 & 0.235 & 5.0 & 109 & 0.047 & 17 & 1970 & 140 \\
\hline FYM 10t /ha+50 \% RF+BF & 7.32 & 0.25 & 0.238 & 5.2 & 119 & 0.056 & 17 & 1975 & 143 \\
\hline FYM 10t/ha+75 \% RF+BF & 7.35 & 0.26 & 0.239 & 5.5 & 125 & 0.059 & 20 & 1982 & 147 \\
\hline FYM 10t/ha+100\%RF+BF & 7.39 & 0.22 & 0.242 & 5.7 & 129 & 0.063 & 22 & 1990 & 151 \\
\hline VC 10t /ha & 7.42 & 0.24 & 0.246 & 5.9 & 131 & 0.062 & 24 & 1992 & 156 \\
\hline VC 10t /ha+50 \% RF & 7.62 & 0.27 & 0.249 & 6.2 & 133 & 0.067 & 25 & 1996 & 161 \\
\hline VC 10t /ha+75\% RF & 7.56 & 0.29 & 0.251 & 6.6 & 139 & 0.069 & 26 & 1998 & 163 \\
\hline VC 10t/ha+100\%RF & 7.42 & 0.25 & 0.255 & 6.8 & 141 & 0.073 & 28 & 2001 & 166 \\
\hline FYM 10t /ha+BF & 7.16 & 0.27 & 0.258 & 7.2 & 146 & 0.070 & 25 & 2010 & 169 \\
\hline FYM 15t /ha & 7.23 & 0.23 & 0.262 & 7.9 & 150 & 0.072 & 27 & 2015 & 170 \\
\hline VC 15t /ha & 7.54 & 0.20 & 0.270 & 8.0 & 152 & 0.076 & 29 & 2019 & 175 \\
\hline $\mathbf{R F}$ & 7.09 & 0.19 & 0.200 & 6.0 & 141 & 0.018 & 12 & 1640 & 160 \\
\hline Control & 7.05 & 0.12 & 0.163 & 3.8 & 70 & 0.012 & 11 & 1530 & 126 \\
\hline C.D. & N.S & N.S & 0.014 & 0.03 & 6 & 0.002 & 1.6 & 105 & 16 \\
\hline
\end{tabular}


Table.2 Carbon mineralization rate as affected by different organic amendments in wheat-guar rotation system at research farm Bawal

\section{Cumulative $\mathrm{CO}_{2}-\mathrm{C}$ evolved (mg/kg soil)}

\begin{tabular}{|c|c|c|c|c|c|}
\hline Treatments & 1 week & 2 week & 3 week & 4 week & $\begin{array}{c}\text { Mineralization } \\
\text { rate } \mathrm{C} \\
\text { (mg/kg/28 days) }\end{array}$ \\
\hline FYM 10t /ha & 61.0 & 48.0 & 30.0 & 9.0 & 5.2 \\
\hline FYM 10t /ha+50 \% RF & 62.0 & 50.0 & 33.0 & 10.0 & 5.5 \\
\hline FYM 10t /ha+75\% RF & 63.5 & 52.0 & 34.0 & 12.0 & 5.7 \\
\hline FYM 10t/ha+100\% RF+PSB+BF & 63.8 & 54.6 & 35.0 & 13.0 & 5.9 \\
\hline FYM 10t /ha+50 \% RF+BF & 64.0 & 52.0 & 34.0 & 16.0 & 5.9 \\
\hline FYM 10t/ha+75 \% RF+BF & 64.0 & 54.0 & 37.0 & 15.0 & 6.0 \\
\hline FYM 10t/ha+100\% RF+BF & 63.0 & 49.0 & 43.0 & 19.0 & 6.1 \\
\hline VC 10t /ha & 65.0 & 55.0 & 36.0 & 18.0 & 6.2 \\
\hline VC 10t /ha+50 \% RF & 64.3 & 55.0 & 40.0 & 18.0 & 6.3 \\
\hline VC 10t /ha+75\% RF & 62.0 & 51.0 & 34.0 & 32.0 & 6.3 \\
\hline VC 10t/ha+100\% RF & 65.0 & 56.0 & 39.0 & 20.0 & 6.4 \\
\hline FYM 10t /ha+BF & 64.0 & 54.0 & 33.0 & 31.0 & 6.5 \\
\hline FYM 15t /ha & 70.0 & 53.0 & 35.0 & 29.0 & 6.6 \\
\hline VC 15t /ha & 80.0 & 51.0 & 34.0 & 27.0 & 6.8 \\
\hline RF & 42.0 & 28.0 & 18.0 & 11.0 & 3.5 \\
\hline Control & 42.0 & 27.0 & 16.0 & 10.0 & 3.3 \\
\hline C.D. & & & & & 0.4 \\
\hline
\end{tabular}


Table.3 Potentially mineralizable nitrogen after 30 days of incubation as affected by different organic amendments in wheat-guar rotation system at Bawal

\begin{tabular}{|c|c|c|c|c|c|c|c|}
\hline \multirow{3}{*}{ Treatments } & \multicolumn{6}{|c|}{ Days of incubation } & \multirow{3}{*}{$\begin{array}{c}\text { Mineralized } \\
\mathbf{N} \\
\text { mg/kg/30 days }\end{array}$} \\
\hline & \multicolumn{3}{|c|}{$\mathbf{0}$} & \multicolumn{3}{|c|}{30} & \\
\hline & $\mathrm{NH}_{4}{ }^{+}-\mathrm{N}$ & $\mathrm{NO}_{3}{ }^{-}-\mathrm{N}$ & $\begin{array}{c}\text { Total } \\
\text { Mineral N }\end{array}$ & $\mathrm{NH}_{4}{ }^{+}-\mathrm{N}$ & $\mathrm{NO}_{3}{ }^{-}-\mathrm{N}$ & $\begin{array}{c}\text { Total } \\
\text { Mineral N }\end{array}$ & \\
\hline FYM 10t /ha & 5.2 & 17.6 & 22.8 & 19.0 & 25.3 & 44.3 & 21.5 \\
\hline FYM 10t /ha+50 \% RF & 16.0 & 31.0 & 47.0 & 24.0 & 46.0 & 70.0 & 23.0 \\
\hline FYM 10t /ha+75\% RF & 10.0 & 30.0 & 40.0 & 15.0 & 50.0 & 65.0 & 25.0 \\
\hline FYM 10t/ha+100\% RF+ PSB+BF & 16.0 & 35.0 & 51.0 & 28.0 & 49.0 & 77.0 & 26.0 \\
\hline FYM 10t /ha+50 \% RF+BF & 12.0 & 36.0 & 48.0 & 29.0 & 46.0 & 69.0 & 27.0 \\
\hline FYM 10t/ha+75 \% RF+BF & 14.0 & 34.0 & 48.0 & 25.0 & 52.0 & 77.0 & 29.0 \\
\hline FYM 10t/ha+100\% RF+BF & 10.0 & 32.0 & 42.0 & 27.0 & 45.0 & 72.0 & 30.0 \\
\hline VC 10t /ha & 12.0 & 30.0 & 42.0 & 35.0 & 40.0 & 75.0 & 33.0 \\
\hline VC 10t /ha+50 \% RF & 15.5 & 33.0 & 48.5 & 36.0 & 47.0 & 83.0 & 34.5 \\
\hline VC 10t /ha+75\% RF & 9.2 & 36.0 & 45.2 & 26.0 & 54.0 & 80.0 & 34.8 \\
\hline VC 10t/ha+100\% RF & 8.0 & 34.0 & 42.0 & 35.0 & 45.0 & 80.0 & 38.0 \\
\hline FYM 10t /ha+BF & 10.0 & 36.0 & 46.0 & 37.0 & 49.0 & 86.0 & 40.0 \\
\hline FYM 15t /ha & 11.0 & 37.0 & 48.0 & 38.0 & 50.5 & 88.5 & 40.5 \\
\hline VC 15t/ha & 9.0 & 35.0 & 44.0 & 38.5 & 47.0 & 85.5 & 41.5 \\
\hline RF & 4.8 & 11.6 & 16.4 & 12.0 & 24.8 & 36.8 & 20.4 \\
\hline Control & 8.6 & 15.1 & 23.7 & 20.2 & 23.1 & 43.3 & 19.6 \\
\hline C.D & & & & & & & 1.27 \\
\hline
\end{tabular}




\section{Potentially mineralizable nitrogen}

Potentially mineralizable nitrogen (PMN) is determined as the net flux of inorganic $\mathrm{N}$ from the mineralizable fraction and it indicates the balance between mineralization and immobilization by soil microbes. Nitrogen mineralization is often measured to access the capacity of soil organic matter to supply inorganic $\mathrm{N}$ in the form of nitrate which is the main form of plant available nitrogen.

Potentially mineralizable nitrogen as affected by different organic amendments in wheatguar rotation system at Bawal has been given in Table 3. Potentially mineralizable nitrogen ranged from 19.6 to $41.5 \mathrm{mg} / \mathrm{kg}$ soil and highest amount was recorded in soils receiving VC @ 15t /ha. Potentially mineralizable nitrogen was $2.5 \%$ higher in soil receiving VC @ 15t /ha than in soil receiving FYM @ 15t /ha and was lowest with inorganically fertilized soils. These results suggested that a larger mineralizable $\mathrm{N}$ pool in organic manure that might have bulid up from continuous use of organic amendments. The lower PMN in soils with inorganic fertilizers may be due to microbial immobilization of nutrients. Debosz et al. (2002) also observed that compost amendments had increased PMN by a factor of 1.8 .

\section{Biological activity}

The microbial biomass carbon (MBC) in different soils ranged from 162 to $320 \mathrm{mg} / \mathrm{kg}$ soil (Figure 1), microbial biomass nitrogen (MBN) from 25 to $40 \mathrm{mg} / \mathrm{kg}$ soil (Figure 2) and microbial biomass phosphorus (MBP) from 8.0 to $12.0 \mathrm{mg} / \mathrm{kg}$ soil (Figure 3) under wheat-guar rotation system at Bawal. Highest microbial biomass $\mathrm{C}, \mathrm{N}, \mathrm{P}$ was observed in soils receiving VC @ 15t /ha followed by treatments receiving a combination of FYM and inorganic fertilizers. The biomass $\mathrm{C} / \mathrm{N}$ ratio increased from 6.4 to 8.0 and $\mathrm{C} / \mathrm{P}$ ratio from 20.0 to 26.6. Goyal et al. (2000) studied microbial biomass $\mathrm{C}, \mathrm{N}$ and nitrifying activities along with other physicochemical parameters of soil such as organic matter, mineralizable carbon and nitrogen in a 100 $\mathrm{cm}$ deep andosol profile in an arable field in Matsudo city, central Japan. Microbial biomass $\mathrm{C}$ and $\mathrm{P}$ were highest at $15-20 \mathrm{~cm}$ depth, whereas microbial biomass $\mathrm{C}$ and $\mathrm{N}$ were highest i.e 202 and $26 \mathrm{mg} \mathrm{kg}$ soil, respectively at $15-20 \mathrm{~cm}$, and these parameters showed a tendency to decrease with depth. Similar observations have also been reported by Boggs et al. (2000) who found highest microbial biomass $\mathrm{C}$ in soils treated with organic manures followed by inorganic fertilizers.

Leite et al. (2009) also found that soil microbial biomass was significantly greater in organic management regimes as compared to conventional management. The long-term studies of Gong et al. (2009) and Kong et al. (2011) also showed that application of organic matter to soil resulted in an increase in microbial biomass and activities.

\section{References}

Anik, M.F.A., Rahman, M.M., Rahman, G.K.M.M., Alam, M.K., Islam, M.S., Khatun, M.F.2017. Organic amendments with chemical fertilizers improve soil fertility and microbial biomass in RiceRice-Rice triple crops cropping systems. Open J. Soil Sci.7 :87-100.

Appireddy, G. K., Saha, S., Mina, B. L., Kundu, S., Govindan, S. and Gupta, H. S. 2008 Effect of organic manures and integrated nutrient management on yield potential of bell pepper (Capsicum annuum) varieties and on soil properties. Arch. of Agron. Soil Sci. 54: 127-137.

Araujo, A. S. F., Santos, V. B and Monteiro, R. T. R. 2008 Responses of soil microbial 
biomass and activity for practices of organic and conventional farming systems in Piauí state, Brazil. Euro. J. Soil Biol. 44: 225-230.

Bhandari, A.L., Ladha, J.K., Pathak, H., Padre, A.T., Dawe, D. and Gupta, R.K. 2002. Yield and soil nutrient changes in a longterm rice-wheat rotation in India. Soil Sci. Soc. Am. J. 66: 162-170.

Boggs, C. L., Kennedy, A. C. and Reganold, J. P. 2000 Organic and biodynamic management: Effects on soil biology. Soil Sci. Soc. Am. J. 64: 1651-1659.

Brookes, P. C., Powlson, D. S. and Jenkinson, D. S. 1982 Measurement of microbial biomass phosphorus in soil. Soil Biol. Biochem. 14: 319-329.

Chang, E.H., Wang,C.H., Chen,C.L. and Chung,R.S.2014 Effects of long-term treatments of different organic fertilizers complemented with chemical $\mathrm{N}$ fertilizer on the chemical and biological properties of soils. J. Soil Sci. Plant Nutr. 60:499511.

Clark, M. S., Horwath, W. R., Shennan, C. and Scow, K. M. 1998 Changes in soil chemical properties resulting from organic and low input farming practices. J. Agron. 90: 662-671.

Debosz, K., Petersen, S. O., Kure, L. K. and Ambus, P. 2002 Evaluating effects of sewage sludge and household compost on soil physical, chemical and microbiological properties. Appl. Soil Ecol. 19: 237-248.

Frazão, L. A., Piccolo, M. C., Feigl, B. J., Cerri, C. C. and Cerri, C. E. P. 2010 Inorganic nitrogen, microbial biomass and microbial activity of a sandy Brazilian Cerrado soil under different land uses. Agric. Ecosyst. Environ. 135: 161-167.

Gami, S.K., Ladha, J.K., Pathak, H., Shah, M.P., Pasuquin, E., Pandey, S.P., Hobbs, P.R., Joshy, D. and Mishra, R. 2001. Long-term changes in yield and soil fertility in a 20-year rice wheat experiment in Nepal. Biology and Fertility of Soils 34: 73-78.

García, C., Hernandez, T., Pascual, J. A.,
Moreno, J. L. and Ros, M. 2000 Microbial activity in soils of SE Spain exposed to degradation processes. Strategies for their rehabilitation. In: C. García and T. Hernandez, Editors, Research and Perspectives of Soil Enzymology in Spain, Consejo Superìor de Investìgacìones Cìentificas, Madrid. 93-143.

García-Ruiz, R., Ochoa, V., Belén Hinojosa, M. and Carreira, J. A. 2008 Suitability of enzyme activities for the monitoring of soil quality improvement in organic agricultural systems. Soil Biol. Biochem. 40: 2137-2145.

Gharib, F. A., Moussa, L. A. and Massoud, O. N. 2008 Effect of compost and biofertilizers on growth, yield and essential oil of sweet marjoram (Majorana hortensis) plant. Int. J. Agric.. Biol. 10: 381-387.

Gil-Sotres, F., Trasar-Cepeda, C., Leirós, M.C. and Seoane, S. 2005 Different approaches to evaluating soil quality using biochemical properties. Agric. Ecosyst. Environ. 37: 877-887.

Goyal, S., KazunoriI, S., Kazuyuki, I. and Kunihiko, K. 2000 Long-term effects of inorganic fertilization and organic amendments on soil organic matter and soil microbial properties in Andisols. Microbes Environ. 15: 143-150.

Jackson, M.L., 1973. Soil Chemical Analysis. Prentice-Hall of India Pvt. Ltd., New Delhi, India, pp. 38-204.

Kalembassa, S. J. and Jenkinson, D. S. 1973 A comparative study of titrimetric and gravimetric methods for determination of organic carbon in soil. J. Sci. Food Agric. 24: 1089-1090.

Keeney, D. R. and Bremner, J. M. 1965 Comparison and evaluation of laboratory methods of obtaining an index of soil nitrogen availability. J. Agron. 58: 498503.

Kong, A.Y.Y., Scow, K.M., Córdova-Kreylos, A.L., Holmes, W.E. and Six, J. 2011 Microbial community composition and carbon cycling within soil 
microenvironments of conventional, lowinput, and organic cropping systems. Soil Biol Biochem. 43: 20-30.

Gong, W., Yan, X., Wang, J., Hu, T.and Gong, Y. 2009 Long-term manure and fertilizer effects on soil organic matter fractions and microbes under a wheat-maize cropping system in northern China. Geoderma 149: 318-324.

Leirós, M. C., Trasar-Cepeda, C., Seoane, S. and Gil-Sotres, F. 2000 Biochemical properties of acid soils under climax vegetation (Atlantic oakwood) in an area of the European temperate-humid zone. Soil Biol. Biochem. 32: 733-745.

Leite, L. F. C, Santos, V. B. and Carneiro, R. F. V. 2009 Soil microbial activity in conventional and organic agricultural systems. Sustainability 3: 268-276.

Lindsay, W.L. and Norvell, W.A. 1978 Development of a DTPA soil test for zinc, iron, manganese, and copper. Soil Sci. Soc. Am. J. 42: 421-428.

Mahmood, F., Khan, I., Ashraf,U.,Shahzad,T., Hussain, S., Shahid, M., Abid, Ullah, M.S. 2017. Effects of organic and inorganic manures on maize and their residual impact on soil physico-chemical properties. J. Soil Sci. Plant Nutr. 17:2232.

Mandal, A., Patra, A. K., Singh, D., Swarup, A. and Masto, R. E. 2007) Effect of longterm application of manure and fertilizer on biological and biochemical activities in soil during crop development stages. Bioresour. Technol. 98: 3585-3592.

Monaco, S., Hatch, D. J., Sacco, D., Bertora, C. and Grignani, C. 2008 Changes in chemical and biochemical soil properties induced by $11-\mathrm{yr}$ repeated additions of different organic materials in maize-based forage systems. Soil Biol. Biochem. 40: 608-615.

Olsen, S. R., Cole, C. V., Watanbe, F. S. and Dean, L. A. 1954 Estimation of available phosphours in soil by extraction with sodium bicarbonate. U.S. Department of Agricultural Circular. 139.

Pramer, C. and Schmidt, A. (1964). Organic matter. In : Methods of soil analysis, part II, C.A. Black (ed.). pp.1395-1397. Am. Soc. Agron. Madison, Wisconsin, USA.

Pruden, G., Kalembassa, S. J. and Jenkinson, D. S. 1985 Reduction of nitrate prior to Kjeldahl digestion. J. Sci. Food Agric. 19: 159-164.

Sangshetty, R. and Babalad, H. B. 2011 Effect of different sources of organic manures on soil properties under organic cotton production system. Internat. J. agric. Sci. 7: 88-92.

Sharma, P., Singh, G. and Singh R. P. 2011 Conservation tillage, optimal water and organic mutrient supply enhance soil microbial activities during wheat (Triticum Aestivum L.) cultivation. Brazilian J. Microbiol. 42: 630-639.

Subbiah, B.V. and Asija, G.L.1956 A rapid procedure for the determination of available nitrogen in soil, Curr. Sci.25:259-260.

Vance, E. D., Brookes, P. C. and Jenkinson, D. S. 1987 An extraction method for measuring soil microbial biomass carbon. Soil Biol. Biochem. 19: 703-707.

\section{How to cite this article:}

Nisha Verma and Sneh Goyal. 2018. Effect of Organic Manuring and Integrated Nutrient Management on Microbiological Properties in Sandy Soils under Wheat-Guar Cropping System. Int.J.Curr.Microbiol.App.Sci. 7(02): 1340-1351. doi: https://doi.org/10.20546/ijcmas.2018.702.163 